\title{
Sealing of calcified plaques after bioresorbable scaffold implantations: a five-year follow up
}

\author{
Erhan Tenekecioglu ${ }^{1}$ - Christos V. Bourantas ${ }^{2,3} \cdot$ Yoshinobu Onuma ${ }^{1} \cdot$ \\ Patrick W. Serruys ${ }^{1,4,5}$
}

Received: 18 November 2016 / Accepted: 28 November 2016 / Published online: 21 December 2016

(C) The Author(s) 2016. This article is published with open access at Springerlink.com

Optical coherence tomography (OCT) has been the imaging technique for detection of scaffold malapposition during implantation, the method of choice at follow up for assessing strut resorption and measurement of cap thickness overlying atherosclerotic plaques [1]. Bioresorbable scaffold (BRS) has the capability of sealing plaque by creating a neointimal cap [2]. Herewith, we present three cases from Absorb Cohort-B trial exhibiting the evolution of neointimal tissue overlying calcified plaques at 5-year postimplantation. The scaffolds were assessed on OCT after implantation, at 1-, 3- and 5-year follow ups.

Coronary artery calcification is a risk factor for coronary adverse events [3]. Despite lower radial strength as compared to the metallic equivalent, Absorb is capable to stretch the non-calcified sectorial segment of the vessel lumen while creating a neointimal cap overlying the calcified plaques thereby refurbishing the endoluminal lining at that specific site (Fig. 1). Through its sealing function, Absorb further isolates the calcified plaques from the lumen and the flowing blood.

Bioresorbable scaffolds may be a treatment option for calcified plaques by inducing a neointimal cap at follow up. The advantage of biodegradable device compared to the metallic stent is temporary vessel scaffolding which reduces the inflammatory response in treated segments at follow up. Reduced inflammation with re-capping may decrease the vulnerability risk of the plaques.

Patrick W. Serruys

patrick.w.j.c.serruys@pwserruys.com

1 Department of Interventional Cardiology, Erasmus

University Medical Center, Rotterdam, The Netherlands

2 Department of Cardiolovascular Sciences, University College of London, London, UK

3 Department of Cardiology, Barts Health NHS Trust, London, UK

4 Imperial College, London, UK

5 Emeritus Professor of Medicine Erasmus University, Rotterdam, The Netherlands 

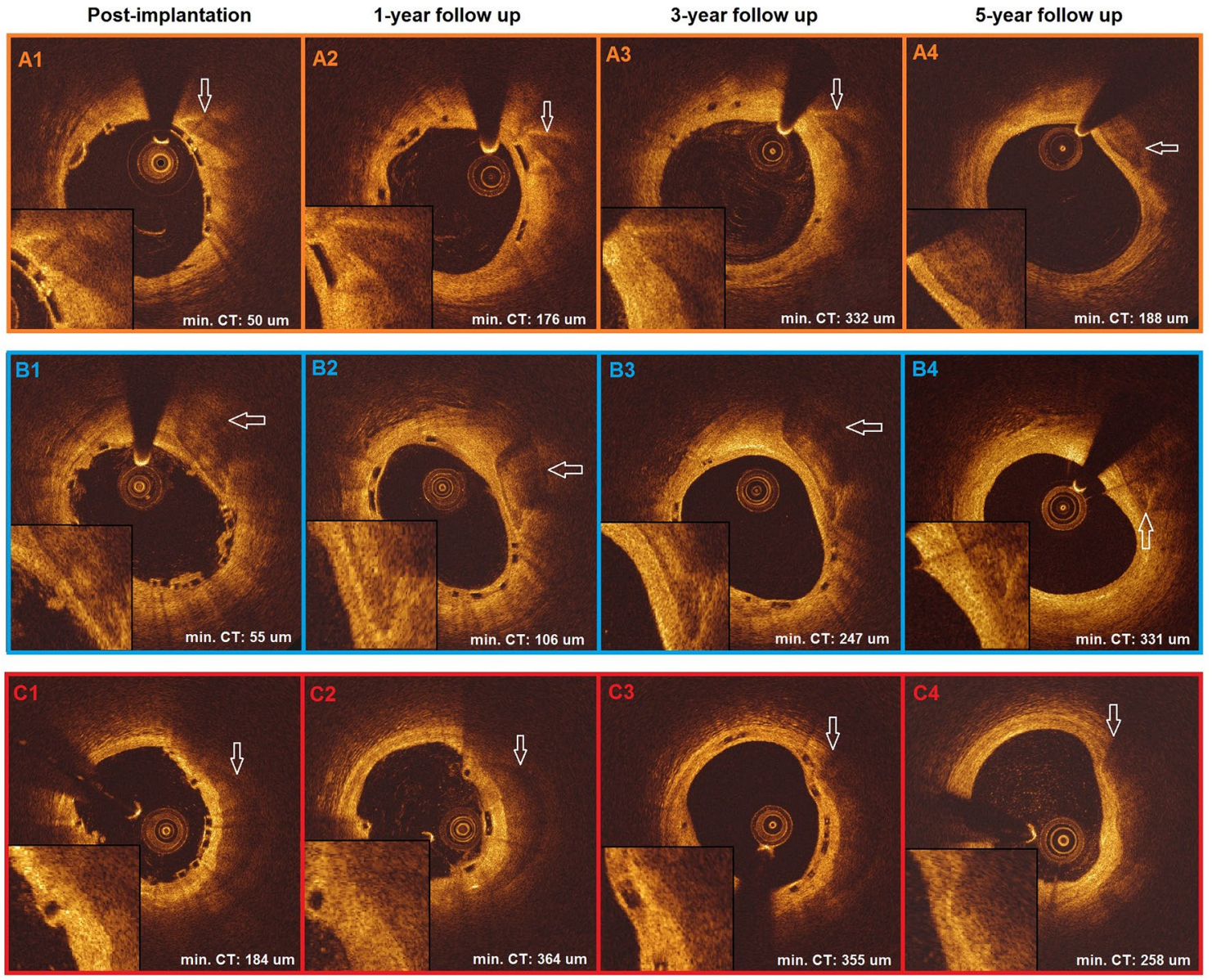

Fig. 1 Three cases from Absorb Cohort-B trial demonstrate calcified plaques covered by scaffold struts after post implantation $(A 1$, $B 1, C 1)$ in optical coherence tomography images. At 1-year $(A 2, B 2$, $C 2)$ and 3-year follow-ups $(A 3, B 3, C 3)$, scaffold struts and progress of neointima at 1-year and at 3 -years, sealing the calcified plaques,

\section{Compliance with ethical standards}

Conflict of interest The authors declare that they have no conflict of interest.

Informed consent Informed consent was obtained from all individual participants included in the study.

Ethical approval All procedures were in accordance with the ethical standards of the institutional research committee and with the 1964 Helsinki declaration and its later amendments.

Open Access This article is distributed under the terms of the Creative Commons Attribution 4.0 International License (http:// creativecommons.org/licenses/by/4.0/), which permits unrestricted use, distribution, and reproduction in any medium, provided you give appropriate credit to the original author(s) and the source, provide a link to the Creative Commons license, and indicate if changes were made. could be observed. At 5-year follow up (A4, B4, C4), after resorption of the struts has been completed, the calcified plaques are definitely sealed by the overlying neointimal tissue that has a tendency to shrink and reflect more intensively ( $\min C T$ minimum cap thickness)

\section{References}

1. Prati F, Guagliumi G, Mintz GS, Costa M, Regar E, Akasaka T, Barlis P, Tearney GJ, Jang IK, Arbustini E, Bezerra HG, Ozaki Y, Bruining N, Dudek D, Radu M, Erglis A, Motreff P, Alfonso F, Toutouzas K, Gonzalo N, Tamburino C, Adriaenssens T, Pinto F, Serruys PW, Di Mario C, Expert's OCTRD (2012) Expert review document part 2: methodology, terminology and clinical applications of optical coherence tomography for the assessment of interventional procedures. Eur Heart J 33:2513-2520

2. Bourantas CV, Papafaklis MI, Kotsia A, Farooq V, Muramatsu T, Gomez-Lara J, Zhang YJ, Iqbal J, Kalatzis FG, Naka KK, Fotiadis DI, Dorange C, Wang J, Rapoza R, Garcia-Garcia HM, Onuma Y, Michalis LK, Serruys PW (2014) Effect of the endothelial shear stress patterns on neointimal proliferation following drug-eluting bioresorbable vascular scaffold implantation: an optical coherence tomography study. JACC Cardiovasc Interv 7:315-324

3. Vliegenthart R, Oudkerk M, Hofman A, Oei HH, van Dijck W, van Rooij FJ, Witteman JC (2005) Coronary calcification improves cardiovascular risk prediction in the elderly. Circulation 112:572-577 